\title{
Actin in human colon adenocarcinoma cells with different metastatic potential ${ }^{\star}$
}

\author{
Dorota Nowak ${ }^{1}$, Agnieszka Krawczenko ${ }^{2}$, Danuta Duśs ${ }^{2}$ and \\ Maria Malicka-Błaszkiewicz ${ }^{1 凶}$ \\ ${ }^{1}$ Department of Cell Pathology, Institute of Biochemistry and Molecular Biology, University of Wroctaw, \\ Wroctaw, Poland; ${ }^{2}$ Institute of Immunology and Experimental Therapy, Polish Academy of Sciences, \\ Wroctaw, Poland
}

Received: 20 October, 2002; revised: 04 November, 2002; accepted: 12 November, 2002

Key words: actin, state of actin polymerization, colon adenocarcinoma cell lines

\begin{abstract}
Four human colon adenocarcinoma cell line variants with different metastatic potential were used to examine whether a correlation exists between actin level, state of actin polymerization and invasiveness of tumour cells.

Monomeric (G), total (T) and filamentous (F) actin were determined in the cytosolic fraction of these cells. A statistically significant decrease in $\mathrm{G}$ actin level and increase in the state of actin polymerization (measured by $F: G$ actin ratio) were found in the cytosol of three cell variants with higher metastatic potential and invasiveness (EB3, 3LNLN, 5W) compared with the parental cell line (LS180).

Our experimental data lead to the conclusion that there is a correlation between the metastatic capacity of human colon adenocarcinoma cells and the state of actin polymerization.
\end{abstract}

Actin is the most abundant and highly conserved protein occurring in all eukaryotic cells. Actin microfilaments are one of the three major components of the cytoskeleton, the structure involved in many cellular functions, including cell motility, contractile ring formation during cytokinesis, maintenance of cell shape, and signal transduction. The structural and motile functions of actin are possible through a dynamic conversion between monomeric actin ( $G$ actin) and filamentous actin (F actin), a linear polymer of $\mathrm{G}$ actin subunits (Sheterline et al., 1998).

\footnotetext{
${ }^{\star}$ The results work were presented in part at the 38th Meeting of the Polish Biochemical Society in Wrocław, September, 2002.

${ }^{凶}$ To whom correspondence should be addressed: Maria Malicka-Błaszkiewicz, Department of Cell Pathology, Institute of Biochemistry and Molecular Biology, University of Wrocław, S. Przybyszewskiego 63, 51-148 Wrocław, Poland; tel.: (48 71) 375 6205; fax: (48 71) 375 6234; e-mail: mmb@ibmb.uni.wroc.pl

Abbreviations: DNase I, deoxyribonuclease I from bovine pancreas (EC 3.1.21.1); DTT, dithiothreitol; i.i., intrailleal; i.s., intrasplenic; i.v., intravenous; PBS, phosphate-buffered saline.
} 
Adhesion and locomotion are one of the key capabilities of cells in tumour growth and metastasis formation. They depend on the architecture of cytoskeletal elements and especially on the actin microfilaments system. The alterations in actin organization are known to accompany malignant transformation of many cell types (Ben-Ze'ev, 1985; Hansell et al., 1995; Button et al., 1995). The disruption of actin stress fibers, as observed in many cancer cells, may result from the changes in actin content and its ability to polymerize and also from a lack of physiological equilibrium between actin assembly and disassembly, so important for its functions.

Interesting data have accumulated on the relation between actin organization, changes in actin isoforms expression and the ability of cancer cells to form metastases (Pokorna et al., 1994; Janmey \& Chaponnier, 1995; Nowak \& Malicka-Błaszkiewicz, 1999). Differences in actin distribution were observed in populations of sarcoma cells with different metastatic potential, in MDCK (Madine Darby Canine Kidney) cells transformed with Moloney sarcoma virus (Le et al., 1998) and in human salivary gland adenocarcinoma (Suzuki et al., 1998). The invasive variants of these cells contain no stress fibers in contrast to their noninvasive counterparts, which show high organization of the actin cytoskeleton. Cytoplasmic $\beta$ actin was identified to appear at the tips of pseudopodia of invasive cells but not in noninvasive cells (Le et al., 1998; Shestakova et al., 1999).

Our former observation of actin during hepatoma Morris 5123 tumour growth showed that a remarkable increase in total and polymerized actin level in tumour cells coincides with the first metastasis formation to the lungs of tumour bearing rats (MalickaBłaszkiewicz et al., 1995; Nowak et al., 1995).

In this paper four phenotypically well-characterized human colon adenocarcinoma LS180 cell line variants - including those with increased motility and metastatic potential showing different organ localization of metas- tasis were used to examine whether a correlation exists between actin level, state of actin polymerization and invasiveness of tumour cells.

\section{MATERIALS AND METHODS}

Cells. The human colon adenocarcinoma cell line LS180 was obtained from Deutsche Krebsforschungzentrum (Heidelberg, Germany). Endothelial cell line HPLNEC.B3 human microvascular endothelial cells from a peripheral lymph node of a patient with Hodgkin's lymphoma - was isolated and characterized by Kieda et al. (2002). Cell lines and further selected variant sublines were propagated in OptiMEM medium supplemented with $3 \%$ fetal bovine serum (Gibco, Grand Island, NY, U.S.A.). Cells were cultured in 25 $\mathrm{cm}^{2}$ tissue culture flasks at $37^{\circ} \mathrm{C}$ in $5 \% \mathrm{CO}_{2} /$ 95\% humidified air (Falcon or Costar) and passaged weekly, using $0.25 \%$ trypsin $/ 0.05 \%$ EDTA solution (Gibco, Grand Island, NY, U.S.A.).

In vitro selection of LS180 cells with increased affinity for human HPLNEC.B3 endothelial cells. HPLNEC.B3 cells were plated onto the bottom of a 24-well TC plate. The colon carcinoma LS180 cells $\left(1 \times 10^{5}\right.$ cells $/ 100 \mu \mathrm{l}$ ) were superposed onto the upper surface of an $8 \mu \mathrm{m}$, Matrigel-coated nucleopore Transwell filter (Costar, France). After 48-72 h, LS180 cells which had migrated to the lower surface of the filter towards the endothelial cell monolayer were removed by a brief $0.25 \%$ trypsin $/ 0.05 \%$ EDTA treatment, washed and propagated in vitro. The manipulation was repeated three times. The obtained colon cancer subline was named LS180EB3 (EB3).

In vivo selection of colon adenocarcinoma cells. The in vitro selected EB3 cells were passaged in vivo by various routes of inoculation, to select metastatic variants. For animal experiments, athymic $\mathrm{NCr} n u / n u$ male mice, obtained from the National Cancer In- 
stitute, Frederic Cancer Research and Developmental Center (Frederick, MD, U.S.A.) were used. Animal experiments were performed according to the International Laboratory Animal Care Convention. The procedure of selection was applied essentially as described elsewhere for colon adenocarcinoma HT-29 cells (Opolski et al., 1998). Briefly, EB3 cells were injected intrasplenicaly (i.s.), resulting in primary tumours in the spleen and metastasis in the liver. Then a piece of liver metastasis was transplanted orthotopically (into intestinal wall; i.i.). The implanted tumours metastasized preferentially to the liver. The procedure was repeated five times resulting in a highly metastatic variant subline designed as LS180EB3 5W (5W). Metastatic cells suspension from the first i.s. passage was also injected intravenously (i.v.) and metastases in the lymph nodes were collected. In this case the passage was repeated three times, resulting in a variant designed as LS180EB3 3LNLN (3LNLN), metastasizing after i.v. inoculation preferentially to peripheral lymph nodes.

Isolation of cytosolic fractions. Cytosolic fraction was used as a source of actin. Cells were homogenized and cytosol was prepared as described earlier by Malicka-Błaszkiewicz \& Roth (1981). Cells growing on tissue culture dishes were gently washed with PBS, scraped with a rubber policeman and suspended in G actin stabilizing buffer (freshly made) containing $10 \mathrm{mM}$ Tris $/ \mathrm{HCl}, \mathrm{pH}$ 7.4, $0.25 \mathrm{M}$ sucrose, $1 \mathrm{mM}$ DTT, $0.1 \mathrm{mM}$ ATP, $0.1 \mathrm{mM} \mathrm{CaCl}_{2}$ (buffer A). Cells were centrifuged $(100 \times \boldsymbol{g}$, $3 \mathrm{~min}, 4^{\circ} \mathrm{C}$ ) and homogenized with 3 volumes freshly made buffer A in a Dounce homogeniser. Homogenates were centrifuged at $105000 \times \mathbf{g}$ for $1 \mathrm{~h}$, at $4^{\circ} \mathrm{C}$. The high speed supernatant was used as the cytosolic fraction and kept frozen $\left(-70^{\circ} \mathrm{C}\right)$ before actin determination.

Actin measurement. Actin was determined as inhibitor of DNase I from bovine pancreas under standard assay conditions, as described by Malicka-Błaszkiewicz \& Roth (1981). The concentration of monomeric actin (G) was estimated by DNase I inhibition, directly in crude cytosol sample. Total actin (T) content was measured after dilution of samples with buffer A until maximal inhibition of DNase I was reached (Malicka-Błaszkiewicz \& Roth, 1981; Malicka-Błaszkiewicz, 1986).

Filamentous actin (F) was calculated by subtracting the amount of $\mathrm{G}$ actin from total actin $(\mathrm{F}=\mathrm{T}-\mathrm{G})$. The state of actin polymerization was defined by the $F$ actin to $G$ actin ratio (F:G).

One unit of DNase I inhibitor (actin) is the amount which decreases the activity of $20 \mathrm{ng}$ of DNase I by $10 \%$ under standard assay conditions (Malicka-Błaszkiewicz \& Roth, 1981). Actin concentration was expressed in units of DNase I inhibitor per mg of sample protein.

Protein. Protein was determined by standard Lowry procedure (Lowry et al., 1951).

Statistical analysis. All data are reported as mean \pm standard deviation (S.D.), their significance was determined using Student's $t$-test. The significance level was set at $P<0.05$.

\section{RESULTS AND DISCUSSION}

To investigate if there is any correlation between actin pool "behaviour" and metastatic capacity of tumour cells, human colon adenocarcinoma cell lines model was chosen. We selected a panel of human LS180 colon adenocarcinoma cells by in vitro and repeated in vivo selections in immunodeficient $\mathrm{nu} / \mathrm{nu}$ mice (Opolski et al., 1998). The first in vitro selection resulted in a variant with increased affinity towards human endothelial cells of secondary lymphatic organ origin. The in vivo selections, performed by serial implantation of selected cell sublines by different routes (intrasplenic, i.s.; intravenous, i.v.; or intrailleal, i.i.) resulted in several cell variants with higher metastatic activity. They grew preferentially as differentially localized metastasis after implantation via a given route, as compared with the parental cell line (LS180). 
Monomeric and total actin levels were measured in the cytosolic fraction of the human colon adenocarcinoma cell variants. Filamentous actin and the state of actin polymerization were then calculated as described in Material and Methods. The data for the adenocarcinoma selectants (EB3, 3LNLN and 5W) were compared with those obtained for the parental line LS180. The results of the studies are shown in Fig. 1 A-D. Total (T) and filamentous (F) actin levels in the cytosolic fraction of the four cell lines were almost unchanged (Fig. 1 B and C). Only a slight, statistically non-significant $(P<0.05)$ decrease was observed. However, it

$\mathbf{A}$

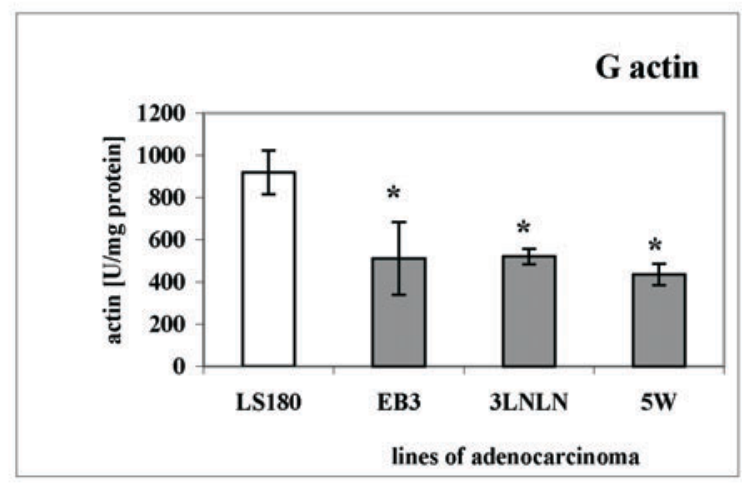

B

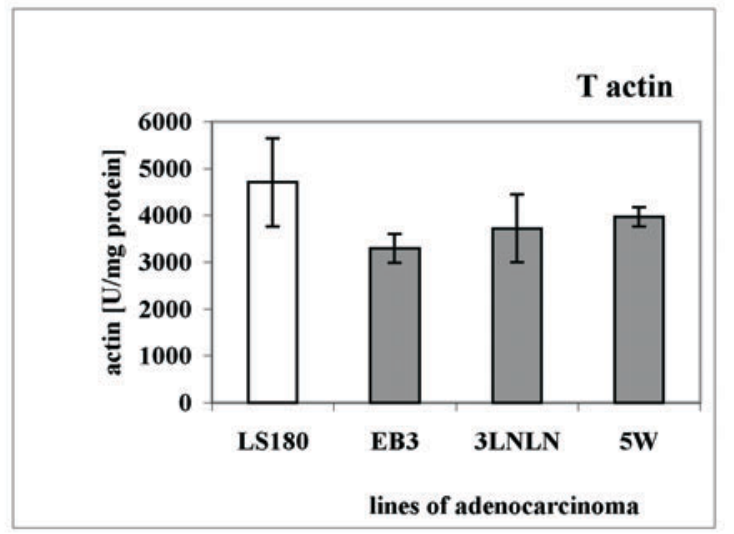

has to be noticed that the amount of $\mathrm{G}$ actin in the three selectants was about two times lower (statistically significant, $P<0.05$ ) compared with the parental line LS180 (Fig. 1 A). The most interesting is the observation of a statistically significant $(P<0.05) \mathrm{F}$ actin to $\mathrm{G}$ actin ratio increase (Fig. $1 \mathrm{D}$ ) in the cell variants with higher metastatic potential and invasiveness (EB3, 3LNLN, 5W) compared with the parental cell line (LS180). Special attention should be paid to the highest value of this ratio in the $5 \mathrm{~W}$ in vivo selectant, obtained by five passages and having the highest metastatic capacity. Our data lead to the conclusion that there is a

C

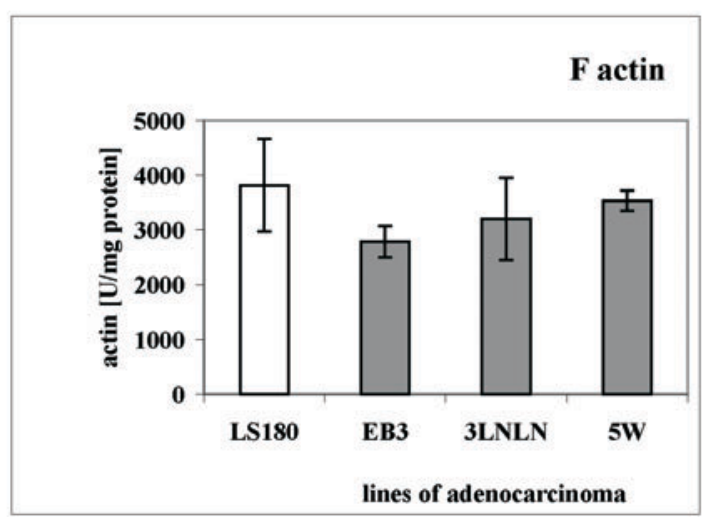

D

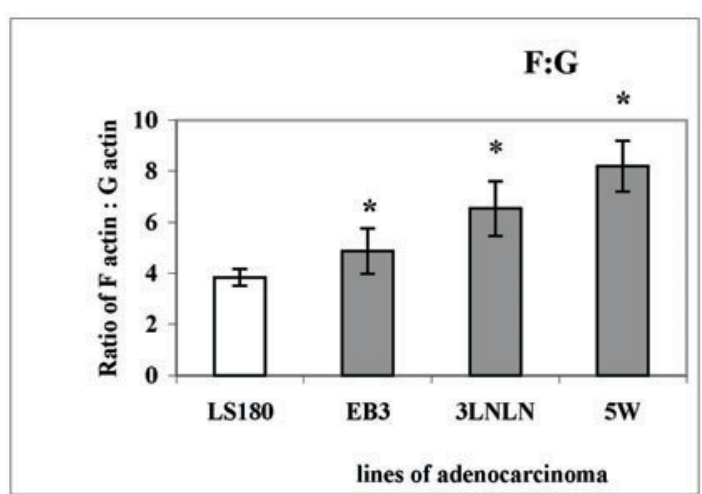

Figure 1. Changes in actin level and its state of polymerization in human colon adenocarcinoma cell lines: LS180 (parental line) and EB3, 3LNLN, 5W (lines with increasing metastatic potential).

Actin was measured as inhibitor of DNase I from bovine pancreas. The different actin forms and the state of polymerization (F:G) were determined as described in Materials and Methods. Bars represent the mean \pm S.D. for data obtained from three independent experiments. *Indicates values significantly different for those for control cells (line LS180) as calculated by Student's $t$-test $(P<005)$. 
distinct correlation between the ability of cells to form metastatsis and the state of actin polymerization as measured by the $\mathrm{F}: \mathrm{G}$ actin ratio.

The concept that tumour invasion is a disease of dysregulated cell motility has gained recognition over the past few years (Kassis et $a l ., 2001)$. There are many collected data on quantitative and qualitative changes of actin in cancer cells. However, they seem often to be controversial, which results from the different experimental models and the difficulties to distinguish between polymerized and monomeric actin level (Katsatonis et al., 1994; Malicka-Błaszkiewicz et al., 1995; Nowak et al., 1995; Stournaras et al., 1996).

There is also a lack of studies on actin in cancer cells of different invasive potential derived from the same parental cell line. This would be convincing model in the respect to evaluation of the results. So far Verschueren et al. (1994) have observed that increased level of $\mathrm{F}$ actin content is correlated with increased motility and malignancy of seleced sublines of T-lymphoma cells. We have shown an increased $\mathrm{F}$ :G actin ratio in human colon adenocarcinoma cell variants with different metastatic potential and invasiveness compared with the parental cell line (Fig. 1 D). This supports the view that high level of actin polymerization is a prerequisite for pseudopod formation - a phenomenon necessary for infiltration of cancer cells into surrounding tissues. The availability of similar data for cells originating from different tumours and selected in respect to their metastatic capacity should help in designing actin targeting drugs to be used in cancer therapy.

\section{R E F E R E N C E S}

Ben-Ze'ev A. (1985) The cytoskeleton in cancer cells. Biochim Biophys Acta.; 780: 197-212.

Button E, Shapland C, Lawson D. (1995) Actin, its associated proteins and metastasis. Cell Motil Cytoskel.; 30: 247-51.
Hansell EJ, Frisch SM, Tremble P, Murnane JP, Werb Z. (1995) Simian virus 40 transformation alters the actin cytoskeleton, expression of matrix metalloproteinases and inhibitors of metalloproteinases, and invasive behaviour of normal and ataxiatelangiectasia human skin fibroblasts. Biochem Cell Biol.; 73: 737-89.

Janmey PA, Chaponnier C. (1995) Medical aspects of the actin cytoskeleton. Curr Opin Cell Biol.; 7: 111-7.

Kassis J, Lauffenburger DA, Turner T, Wells A. (2001) Tumour invasion as dysregulated cell motility. Cancer Biol.; 11: 105-17.

Katsatonis J, Tosca A, Koukouritaki SB, Theodoropoulos PA, Gravanis A, Stournaras C. (1994) Differences in the G/Total actin ratio and microfiament stability between normal and malignant human keratinocytes. Cell Biochem Funct.; 12: 267-74.

Kieda C, Paprocka M, Krawczenko A, Załęcki P, Dupuis P, Monsigny M, Radzikowski C, Duś D. (2002) New human microvascular endothelial cell lines with specific adhesion molecules phenotypes. Endothelium.; 9/4 (in press).

Le PU, Nguyen TN, Drolet-Savoie P, Leclerc N, Nabi LR. (1998) Increased $\beta$-actin expression in an invasive Moloney sarcoma virus-transformed MDCK cell variant concentrates to the tips of multiple pseudopodia. Cancer Res.; 58: 1631-5.

Lowry OH, Rosebrough NJ, Farr AL, Randall RJ. (1951) Protein measurement with the Folin phenol reagent. $J$ Biol Chem.; 193: 265-75.

Malicka-Błaszkiewicz M. (1986) DNase-like activity and actin content in the liver of some vertebrates. Comp Biochem Physiol.; 84B: 207-9.

Malicka-Błaszkiewicz M, Roth JS. (1981) Some factors affecting the interaction between actin in leukemia L1210 cells and DNase I. Biochem Biophys Res Commun.; 102: 594-601.

Malicka-Błaszkiewicz M, Styczeń I, Nowak D, Hańczycowa H, Ponikowski P, Sebzda T. (1995) Actin content and polymerization in 
tumour, liver and serum of the hepatoma Morris 5123 tumour bearing rats. Mat Med Pol.; 27: 115-8.

Nowak D, Malicka-Błaszkiewicz M. (1999) Izoformy aktyny - zróżnicowanie funkcji, zmiany w stanach patologicznych. Post Bioch.; 45: 261-9.

Nowak D, Majcher I, Kochman A, MalickaBłaszkiewicz M. (1995) The changes in actin content and polymerization during hepatoma Morris 5123 tumour development. J Exp Clin Cancer Res.; 14: 37-40.

Opolski A, Wietrzyk J, Duś D, Kieda C, Matejuk A, Makowska A, Wojdat E, Ugorski M, Laskowska A, Kłopocki A, Rygaard J, Radzikowski C. (1998) Metastatic potential and saccharide antigens expression of human colon cancer cells xenotransplanted into athymic nude mice. Folia Microbiol.; 43: 507-10.

Pokorna E, Jordan PW, O’Neill CH, Zicha D, Gilbert CS, Vesely P. (1994) Actin cytoskeleton and motility in rat sarcoma cell populations with different metastatic potential. Cell Motil Cytoskeleton.; 28: 25-33.

Shestakova EA, Wyckoff J, Jones J, Singer RH, Condeelis J. (1999) Correlation of $\beta$-actin messenger RNA localization with metastatic potential in rat adenocarcinoma cell lines. Cancer Res.; 59: 1202-5.

Sheterline P, Clayton J, Sparrow JC. (1998) Protein profile. Actin. Oxford University Press, New York.

Stournaras C, Stiakaki E, Koukouritaki SB, Theodoropoulos PA, Kalmanti M, Fostinis Y, Gravanis A. (1996) Altered actin polymerization dynamics in various malignant cell types: evidence for differential sensitivity to cytochalasin B. Biochem Pharmacol.; 52: 1339-46.

Suzuki H, Nagata H, Shimada Y, Konno A. (1998) Decrease in $\gamma$-actin expression, disruption of actin microfilaments and alterations in cell adhesion systems associated with acquisition of metastatic capacity in human salivary gland adenocarcinoma cell clones. Int $J$ Oncol.; 12: 1079-84.

Verschueren H, Van Der Taelen I, Dewit J, De Braekeleer J, De Baetselier P. (1994) Metastatic competence of BW5147 T-lymphoma cell lines is correlated with in vitro invasiveness, motility and F-actin content. $J$ Leukoc Biol.; 55: 552-6. 